\title{
重拾传统智慧
}

\section{ADAPTING TRADITIONAL WISDOM FOR PRESENT-DAY USE}

杨庭硕
吉首大学历史与文化学院终身教授
湖南省吉首市人民南路120号吉首大学历史与文化学院,
$\begin{aligned} & 401210418 @ q q . c 0 m \\ & \text { Tingshuo YANG } \\ & \text { Tenured Professor of College of History and Culture, } \\ & \text { Jishou University }\end{aligned}$

如何以人类社会发展的视角来理解和评 议传统?

杨庭硕（以下简称杨）：不是所有过去 存在的事物都能被称作 “传统” , 我们不能 只考虑时间这一维度, 还需要注意在历史进 程中必然发生的各种流变，以及事物在空间 中所发生的变化。只有那些前人传下来的、 自成体系的，对一定历史时期的社会生活产 生重大影响的, 且在一定程度上有广泛受众 的事物，才有必要被认定为传统。当然，所 谓的重大影响, 既可以是正面的, 也可以是 负面的。

传统包括三个层次，即与无机自然相关 的传统、与有机生态系统相关的传统，以及
与社会人文相关的传统。

第一个层次是指人类如何与无机世界 打交道。无机世界的存在形式与规律持续的 时间非常长，可能经过上千万年乃至更长时 间才会发生人类可察觉的明显变化。它包括 日出日落、水往低处流、冬冷夏热等自然规 律。例如, 西双版纳属亚热带雨林季风气 候，有史以来，西双版纳的自然环境就以炎 热、潮湿、生机典然为标志。而我们祖先积 累下来的关于这些存在形式的传统知识和技 术技能，可以直接为今人所用。

第二个层次是指如何与有机生态系统打 交道。生态系统由植物、动物、微生物有序 组合而成。由于受到人为干预, 这个层次涉 及的事物可能在较短时期内发生明显变化。

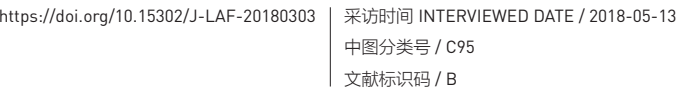

https://doi.org/10.15302/J-LAF-20180303 采访时间 INTERVIEWED DATE / 2018-05-13 中图分类号 / $C 95$ 中图分类号/C95
文献标识码/ B

摘要

受访人杨庭硕为人类学和民族学专家, 其从人类社会发展的视角出 发, 对传统进行了定义和解读, 同时指出传统包括三个层次, 即与无机自 然相关的传统、与有机生态系统相关的传统, 以及与社会人文相关的传 统, 并强调这三个层次各有各的发展规律与延续周期, 但又会相互影响。 而后, 受访人对传统知识和传统智慧进行了辨析, 认为传统智慧维度复 杂、内容丰富, 我们需要以辩证发展观来审视传统智慧的意义, 并说明了 在科学持续发展、技术不断推陈出新的今天强调传统智慧的意义。最后, 受访人指出, 传统智慧对当今的环境建设具有积极贡献, 这些智慧不仅需 要积累和传承, 更需要弘扬和创新, 以在生态文明建设中获得新的适用可 能, 这一点尤为紧迫和必要。

\section{关键词}

传统智慧; 知识; 人类社会发展; 生态文明建设

\section{ABSTRACT}

Tingshuo Yang, the interviewee, is an anthropologist and ethnologist He defines traditions from a perspective of human society development and points out that there are three spheres of traditions, including the ones respectively related to inorganic nature, organic ecosystems, and social customs. Traditions in such three spheres are under independent development laws and cycles, while influencing each other. The interviewee also distinguishes traditional knowledge from traditional wisdom and emphasizes that traditional wisdom is complex in dimensions and rich in contents which requires us to examine and define traditional wisdom with a dialectical, developing outlook. He further underlines the significance of applying the wisdoms in traditions though under nowadays unceasing scientific and technological advance. Finally, Yang argues that how to reactivate and apply such wisdoms for present-day use is one of the pressing and necessary tasks that we are facing today. KEY WORDS

Traditional Wisdom; Knowledge; Human Social Development; Ecological Civilization Construction

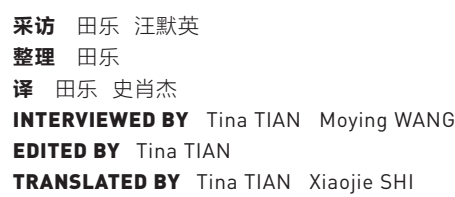


我们的祖先与生态系统打交道所积累的经验 与教训, 则构成了这一层次的传统。这一层 次的传统与我们每个人的生活都密切相关。 因而, 我们只有了解这样的传统, 才可能进 行环境和空间设计。例如，三峡大坝的修建 对于长江下游城镇建设的影响十分显著, 原 因在于相关地区的生态系统已经发生了明显 改变, 改变前形成的传统和改变后的生态系 统很难直接对接。为此, 在理解和认识相关 传统时, 我们就不得不做出相应的调整, 才 能使传统为今人所用。如果忽视了这一点, 机械地照搬老传统，那么相关的环境和空间 设计就会变得文不对题，从而失去预期的意 义和价值。

第三个层次是指人类社会在处理人与人 之间关系的过程中而形成的传统。例如，各 个民族不同的婚姻形式与习俗等。随着时代 的推移, 这一层次的传统会发生明显变化, 但其影响还持续存在。因此，传承也得有改 变和创新, 这才是理解和评议这一层次传统 的正确做法。

我们不能将这三个层次混为一谈, 它 们各有各的发展规律与延续周期。但与此同 时, 这三个层次的传统又会相互影响。举例 来说, 水稻是当今中国人的主要粮食, 其种 植起源于野生稻。唐代的 “两税法” 确定将 稻谷作为国家的主要粮种去征收赋税。将水 稻定位为主粮, 这个从1000多年前延续下 来的传统, 对中国人的生活产生了巨大的影 响。与此同时, 中国的农业生态和景观, 甚 至各民族的文化也都受到了直接或间接影
响——例如, 当我们对稻田景观司空见惯 后, 就会对原始森林充满好奇, 认为其非常 神秘一一然而, 对于平原地区来说, 经营稻 田很容易, 但对于山地丘陵地区来说, 修梯 田种水稻的代价就会很大, 减产的风险也较 高。所以, 云南省元阳县那些壮观的梯田是 千余年来传统稻田经营积淀的产物, 体现了 当地人民与生态环境的互动关系。我们不能 对这样的传统做简单的理解和评议, 在我们 感叹人类创造力的同时，也需意识到其高昂 的经营和维护成本。

我要强调的是, 传统不是指客观存在的 事实, 而是人类对这些事实的认知与传承活 动的结果。不管是哪一个层次的传统, 我们 的祖先都对这些存在形式加人了基于他们所 处时代背景的认知, 并在运用过程中根据特 定的需要进行了篮选、剔除、转化、改造和 强化, 进而形成了我们今天所能感受到的传 统。我们既要珍视这样的传统, 又必须对它 们进行基于历史的理解和评议, 以使其在环 境和空间设计中得到正确的运用。

我们对于传统的评价标准亦是动态变 化的, 即评价标准不具有永恒性, 而需考虑 时代的有效性。因为每个时代都有每个时代 的不同需求, 今天有用的, 明天不一定有 用; 明天有用的，后天也不一定有用。一度 被边缘化的某些传统, 随着时代的变化, 即 使在中断相当长的时间后，也可能重新焕发 生机，成为值得利用的传统。比如，作为天 然生态涂料的发源国，中国生漆和桐油的种 植、贸易和消费历史悠久, 且在世界范围内
影响深远。20世纪中期, 随着化学涂料的发 明, 这两种生态涂料逐渐被取代, 相关的作 物种植也日益减少。但随着时间的推移, 人 们发现化学涂料会挥发有毒气体, 生产过程 也会对环境造成严重污染。在建设 “健康中 国” 的当代, 利用生态涂料这一曾经被边缘 化的传统可能将迎来新一轮的发展契机; 反 过来, 发掘与环境友好型材料和技术相关的 各种传统也成了当代环境和空间设计需要面 对的重大现实问题。

如何辨别什么是知识的传承, 什么是传 统智慧?

杨：人类对某种事物的具体认识是知 识, 而智慧是由知识构成的整个体系, 是指 导人们正确利用知识的哲理思辨感悟。再以 水稻种植为例, 大多数禾本科粮食作物通常 都不需要移栽, 为什么水稻种植要插秧? 这 是因为水稻是一种亚热带湿地生态系统的衍 生物种, 就生物属性而言, 其本身就兼有两 种繁殖方式, 一种是营养繁殖, 即只需分根 便能成片生长; 另外一种是种子繁殖, 只有 当水稻面临生存危机 (或旱、或涝、或碱 等) 的情况下, 它才会为了延续其物种而大 量结实。但在野生稻被驯化后, 人类发现在 良好的生长环境下, 水稻只长根和叶, 反而 不结实。那么如何才能使之结出又大又多的 谷粒, 以满足人类的食物需求? 人类能够找 到的办法就是实施插种。水稻插种的相关知 识与具体技术操作属于人类传承下来的知 
识。而人类通过发现不同物种的不同生长习 性, 摸清它们的规律, 进而针对特定的自然 环境和需要, 找到适宜的对策, 则是一种智 慧。智慧是对如何应用知识所进行的反复思 考, 因而智慧必然高于知识。

传统智慧维度复杂、内容丰富, 需考虑 时间和空间维度，以及民族性、文化性和相 对性。例如, 中国的传统智慧未必适用于美 国; 农耕民族的传统智慧未必适用于狩猎民 族; 淡水地区种植水稻的插秧智慧就不适用 于宁夏地区一一因为当地的水体中盐碱含量 较高, 水稻在这种碱性环境中无需插秧也可 结实。

在不同的文化、不同的时代中，对传 统智慧的定义和评价各不相同, 且随着空间 和时间的变化, 其适用的文化背景也会发生 变化。所以我们需要以辩证发展观来审视传 统智慧的意义, 并思索我们该选什么、丢什 么、发展什么、创新什么, 而不是抱残守 缺, 生搬硬套。费孝通曾经说过 “各美其 美，美人之美，美美与共，天下大同”，对 待传统智慧也应如此。

历史的车轮不断前行, 在科学持续发 展、技术不断推陈出新的今天, 我们强调传 统智慧的意义何在?

杨：现在不少人认为, 时代变了, 那些 被淘汰的传统没有必要找回。这种颇为流行 的观点其实并不全面。

我们需对传统智慧的性质加以辨别。
由于历史性社会原因造成的传统（因某一次 社会事件或某一个历史进程造成的传统，如 清朝统治者要求当时的人们剃发留辫), 在 今天就完全可以淘汰之, 因为其适用的社会 背景已经过去, 也没有必要重演。但是, 还 有许多被时代暂时 “遗忘” 或 “搁置” 的传 统, 如果对今天的社会生活有了新的价值, 那就该另当别论了。举例来说, 在 20 世纪 七八十年代以前, 由于运输条件落后, 杨梅 一直被视为一种最不具备商业价值的水果, 因为它的保鲜期太短。杨梅种植的传统也因 此受到了极大的限制, 相关的种植智慧也大 部分被搁置。现在，由于拥有了高铁、飞机 等运输工具, 从杨梅采摘到出现在异地消费 者的餐桌上仅需几个小时。这说明某个时代 在技术上达不到, 或者不符合当时社会需求 的传统, 随着时代的变迁也许可能被重新启 用。这是我们倡导对传统不能一概而论的依 据所在，这本身就是一种智慧。

\section{传统智慧在当今的环境建设, 特别是生 态文明建设中具有怎样的意义?}

杨: 当今, 中国要进行生态文明建设, 既需要有生态的空间环境, 也需要有生态的 生活方式, 包括我们衣食住行的方方面面, 是一种需要整体建设的系统性工程。传统的 智慧需要积累和传承, 更需要弘扬和创新, 以使这些智慧在生态文明建设中获得新的适 用可能。例如, 尽管鄂伦春、鄂温克等狩猎 民族的猎手不再打猎，但他们运用丰富的传
统狩猎知识和智慧, 掌握了东北虎、野猪等 野生动物的生存及活动规律, 为当今的生物 多样性保护工作做出了重要贡献。靠有经验 的猎手去发现濒临灭绝的东北虎的足迹, 比 花大价钱到处安置摄像头的成效要好得多。 一味地贬低传统知识和智慧, 而不去创新利 用, 同样是一种不能容忍的错误态度, 而在 今天, 强调这一点显得尤为紧迫和必要。LAF

致谢

感谢吉首大学历史与文化学院在读搏土研究生彭兵对于本文的帮助 与贡献。
云南省元阳县梯田

Terraced paddy fields in Yuanyang, Yunnan Province.

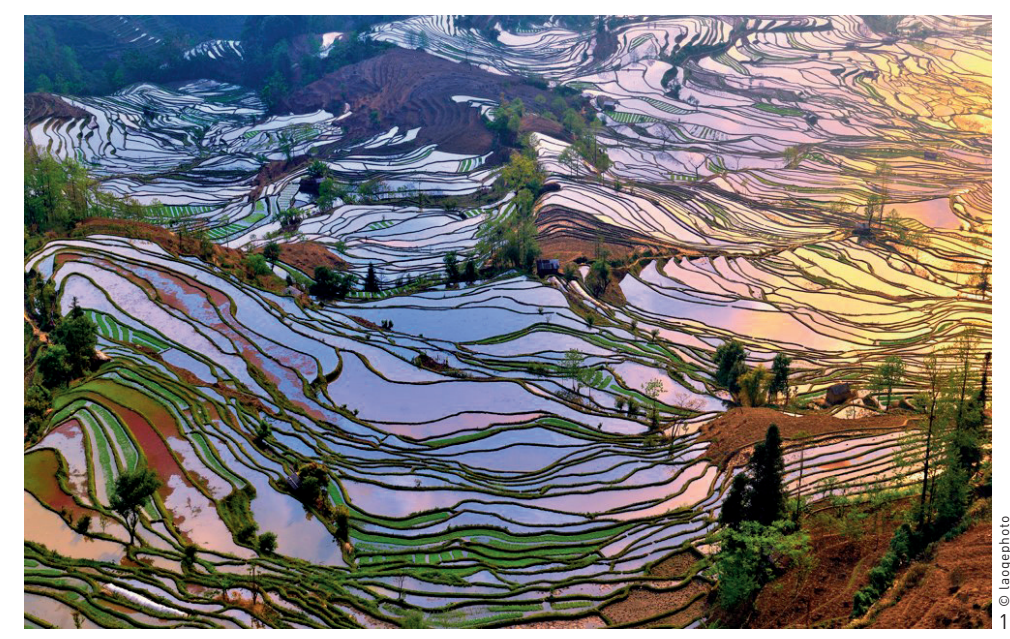




\section{How do you define tradition from a perspective of reviewing the development of human society?}

\section{Tingshuo YANG (YANG hereafter):}

Not all things that happened in the past can be called traditions - Time should not be the only criterion because all inevitable historical evolutions and spatial changes might influence humans' values and behaviors. Traditions are self-contained thoughts or behaviours that are passed down and have exerted significant, wide impact - positively or negatively - on society in certain historical periods.

There are three spheres of traditions, including the ones related to inorganic nature, organic ecosystems, and social customs.

Traditions related to inorganic nature refer to how human beings interact with the world. The natural laws of the inorganic sphere exist and last for a very long time - such like sunrise and sunset, water flows downward, and summer is warm and winter is cold - and changes might take millions of years or even longer to be noticeable by humans. For instance, Xishuangbanna area is all time characterized for its thriving sub-tropical rainforest and monsoon climate. The ancient knowledge and skills passed down from the indigenous ancestors are still in use well.

Organic ecosystem consists of plants, animals, and microorganisms that may be impacted by human intervention and change significantly in a short period of time. The traditions in this sphere are the experience what our ancestors learnt from interacting with organic ecosystems. Such traditions have greatly influenced everyone's life, providing a source of knowledge for environmental and spatial design. For example, the built environments of the cities and towns along the Yangtze River basin have largely changed due to the construction of the Three Gorges Dam project. Because the regional ecosystems had varied dramatically, and human knowledge and practice that go by the local traditions are not suitable to nowadays changed ecosystems any more. Thus, we have to make adjustments and improvement of our understanding on relevant traditions before resorting them. Otherwise, environmental and spatial design would fail to realize its expected meaning and functions.

Traditions related to social customs come from the cultural processes regarding human-social relations. For example, different ethnics have different marriage forms and customs. Although traditions in this sphere change distinctly as time goes on, their influence last. Therefore, we need to understand, examine, celebrate, or innovate such cultural traditions with changing minds.

Traditions in such three spheres are under independent development laws and cycles, while influencing each other. For instance, rice, as one of the staple foods for most Chinese today, originated from wild rice species. In 780, the Two-tax Law adopted in Tang Dynasty promoted the rice cultivation throughout China, which has profoundly influenced not only the life of Chinese people and China's agricultural ecology and landscape, but also the national cultures - when we get accustomed to the open landscape of paddy fields, we would be curious about thick forests and think they are mysterious. In addition, it is easy to operate and maintain paddy fields in flat areas like the North China Plain, while in hilly areas the cost of planting rice and the risk of crop failure are extremely high. The splendid terraced fields in Yuanyang, Yunnan Province is an agricultural heritage accumulated over 1,000 years and reflects the interaction between locals with and the ecosystem. We cannot ignore the high operational and maintenance costs 
when we enjoying the admirable human creativity in the farming tradition for centuries.

What I want to emphasize here is that a tradition does not refer to a fact, but a result of humans' recognition and inheritance activities on facts. All traditions reflect how our ancestors understood, screened, eliminated, transformed, reformed, or strengthened knowledge for specific needs. We take over the traditions and still do the same thing today. We are expected to treasure such legacy while examining and comprehending them from a historical perspective, in order to apply these wisdoms in contemporary environment and spatial design.

At the same time, people's evaluation standards on traditions change over time because in each era people have different specific needs and criteria. So traditions might be marginalized or popular as time changes. For example, China is the origin land of natural coating and has a long history of raw lacquer and tung oil harvest, trading, and consumption, once greatly promoting natural coating worldwide. Since the middle of the 20th century, natural coating had been gradually replaced by chemical coatings, also resulting in a dramatic reduction of lacquer tree and tung tree planting. However, chemical coatings are later proven to emit toxic gases and the related production process would cause serious pollution problems. In the current era of Healthy China construction, the once marginalized natural coating industry would be rejuvenated, which further asks urban planners and designers to explore and apply such traditions in the fields of contemporary environmental and spatial design.

\section{How to distinguish traditional knowledge from traditional wisdom?}

YANG: Knowledge is specific cognitions about certain items, and wisdom is a philosophical and dialectical thinking system of knowledge that guides people to use knowledge properly. Take rice cultivation as an example again. Rice is the only Gramineae crop that requires seedling transplantation, because it is a derivative species from subtropical wetlands and reproduces biologically in two means: one is vegetative reproduction, which means rice can grow through root separation; the other is the seed reproduction, which happens only when rice is endangered by survival threats (such as flood, drought, or saline soil). In the latter condition, rice would yield massive seeds to ensure species continuation. However, it turned out that in domesticated planting environment, wide rice would grow roots and leaves but not yield seeds. The solution to this problem is seedling transplantation manually. In this case, knowledge is the facts and techniques that people have learnt in rice seedling transplantation process, and wisdom is to develop appropriate solutions according to specific needs by learning vegetation's growing habits and laws in different environmental conditions. It can be concluded that wisdom is an accumulated result of repetitive thinking and a reflection on how to utilize knowledge, and it thus is superior to knowledge.

Traditional wisdom is complex in dimensions (including the dimensions of time and space) and rich in contents (such as national and cultural difference and relativity). Say, the wisdoms in Chinese traditions are not necessarily applicable in American cases; the wisdoms in farming traditions may not be useful for hunting activities; the tradition of rice seedling transplantation is practicable in freshwater regions but not applicable in Ningxia area because the water in that region is saline-alkali enough. Therefore, rice can yield seeds without seedling transplantation.

In different cultures and eras, 
traditional wisdom is defined and evaluated differently. Due to the changes of space and time, the relevant cultural context would change as well. It requires us to examine and define traditional wisdom with a dialectical, developing outlook - instead of copying traditions mechanically or anachronistically, we need to scientifically and dynamically consider what to retain, to eliminate, to rejuvenate, or to innovate. Chinese sociologist Xiaotong Fei once commented that "every form of beauty has its uniqueness. It is precious to appreciate other forms of beauty with an inclusive mind. If beauty represents itself with diversity and integrity, then the world would be blessed with harmony and unity." This is the attitude we should adopt towards traditional wisdom.

Under the unceasing scientific and technological advance nowadays, why should we emphasize the significance of the wisdom in traditions?

YANG: Well, many people think that tradition contributes little to today's development because time is always changing. Regrettably, such opinions are prejudiced.

We should distinguish the nature of traditional wisdom dialectically.
The traditions resulted from historical causes (a historical event or course, such as the hair shaving movement promoted by the rulers of Qing Dynasty in China) can surely be abandoned because the applicable social backgrounds had gone and there is no need to resume such traditions. However, some traditions that have been "forgotten" or "set aside" in history may get used today. Take waxberry farming as an example. Limited by poor transportation conditions and the short length for freshness, waxberry was considered as a fruit of least commercial value in the late 1970s and early 1980s, and nobody cared the tradition of waxberry cultivation and related agricultural wisdom. Today, thanks to the rapid development of high-speed railway and airplanes, it only takes a few hours from waxberry picking to consumers' tables. It demonstrates that traditions set aside due to technical limitations may be rediscovered in use as technology advances. Examining traditions with a developing attitude is also a wisdom in itself.

What is the significance of applying traditional wisdom in today's environmental construction, especially in the ecological civilization construction?
YANG: The current ecological civilization construction in China requires establishing both an ecological environment and an ecological lifestyle, covering all aspects of our daily life. The realization of such a systematic agenda also requires comprehensive considerations and holistic approaches. We need not only to accumulate and pass down the wisdoms in traditions, but also to promote, innovate, and make them adaptive to new conditions in the ecological civilization construction. For example, hunters from Oroqen, Evenki, and other hunting ethnics can contribute to nowadays biodiversity protection by using their knowledge of wild animals' living habits - they can tell the quantity, sex, and healthy condition of Siberian tigers or wild boars by identifying their footprints, which is much more efficient in spotting endangered wild animals than by setting expensive recording cameras. It is intolerant to simply depreciate traditional knowledge and wisdoms; how to reactivate and apply the wisdoms for present-day use is one of the pressing and necessary tasks that we are facing today. LAF

\section{ACKNOWLEDGEMENT}

Thanks to Bing Peng, PhD candidate of College of History and Culture, Jishou University, for his great help on this article. 